HPV 16 detection in cervical lesions, physical state of viral DNA and changes in p53 gene

\author{
Department of Microbiology and Parasitology, Biomedical Institute, \\ Universidade Federal Fluminense, Niterói, Rio de Janeiro, Brazil
}

\section{........ INTRODUCTIION}

In the last decade, breast cancer has become the highest cause of morbidity and mortality among female malignancies, but cervical cancer represents the leading cause of cancer-related deaths among women in developing countries, including Brazil. ${ }^{1}$ Nearly 40,000 cases of cervical cancer arise among Brazilian women every year. ${ }^{2}$ Lopes et al., studying the behavior of Brazilian women in the light of cervical cancer prevention, verified that most people had not undergone preventive examinations. ${ }^{3}$ Uterine cervical cancer and non-specific uterine cancer combined are the second greatest underlying cause of death due to neoplasms for women aged 30-49 in the state of São Paulo. ${ }^{4}$

Evidence from laboratory and epidemiological studies has shown an association between human papillomavirus (HPV) infection and both cervical cancer and pre-cancerous neoplasias. ${ }^{5,6}$ High-risk HPV types like HPV 16 and 18 have been strongly linked to cervical carcinoma. ${ }^{7}$ In addition to HPV 16 being common in the general population, it remains among the most prevalent individual type in cervical neoplasias. ${ }^{8}$

High-risk HPVs can integrate into host cell DNA, and this is essential data regarding cancer development. Viral integration promotes the disruption of the HPV E2 gene leading to unregulated increases in the E6 and E7 proteins. ${ }^{9}$ These viral proteins of oncogenic $\mathrm{HPV}$ inactivate the products of $\mathrm{p} 53$ and $\mathrm{Rb}$ tumor suppressor genes, respectively. The tumor suppressor gene functions include regulation of the cell cycle and the cellular response to DNA damage, initiation of DNA repair and replication, induction of apoptosis and promotion of cell differentiation. ${ }^{10}$ Inactivation of the p53 tumor suppressor gene is correlated to a critical step in the development of many human cancers. ${ }^{11}$ It may result from a number of events including mutation of the p53 gene (with or without associated allelic deletions) and binding of the $\mathrm{p} 53$ to cellular or viral proteins. In cervical carcinoma, loss of p 53 function can occur by interaction with E6 protein of high-risk HPV types. ${ }^{12}$

In this work, we conducted a study on a group of women referred to our public health service for assessment of cytological/histological abnormalities in genital lesions. We detected HPV type 16 infection, the physical status of viral DNA and $\mathrm{p} 53$ gene alterations.

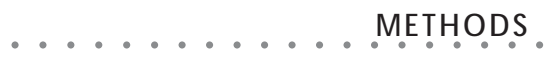

We studied 43 consecutive women attended at Hospital Universitário Antônio Pedro of the Universidade Federal Fluminense, Rio de Janeiro, between April 2000 and June 2002. These women have litlle or no access to routine, annual Papanicolaou exams in local services and were referred to our hospital for investigation of different kinds of cervical lesions. Colpocytology test screening was performed at the first or subsequent visit to our clinic. The age range was 18-68 years with an average of 37.8 years, with a standard deviation of 11.9.

Two cervical smears containing ectocervical and endocervical cells were taken from each patient, one of them placed in TE buffer (Tris $10 \mathrm{mM} \mathrm{pH} \mathrm{7.4,} \mathrm{EDTA} 1 \mathrm{mM}$ - ethylene diamine tetraacetic acid $-1 \mathrm{mM}$ ) and stored at $-20^{\circ} \mathrm{C}$ and the other destined to $\mathrm{Pa}$ -
- Ledy do Horto dos Santos Oliveira

- Eliane de Vasconcelos Machado Rodrigues

- Ana Paula Terra Alvim de Salles Lopes

- André de Paula Fernandez

- Silvia Maria Baeta Cavalcanti papillomavirus (HPV) has been linked to cervical carcinoma. Integration of viral DNA into host cell DNA is essential for this cancer development, promoting disruption of the HPV E2 gene, thus leading to unregulated increases in E6 and E7 proteins and inactivating the products of $\mathrm{p} 53$ and $\mathrm{Rb}$ tumor suppressor genes.

OBJECTIVE: To investigate HPV 16 infection in cervical lesions, physical state of viral DNA and p53 gene alterations in a group of women attending a public health service.

DESIGN: Prospective, non-controlled, transversal study

SETTING: Gynecological clinic of the School od Medicine, Universidade Federal Fluminense.

SAMPLE: 43 consective patients with cervical lesions referred to our service.

MAIN MEASUREMENTS: Cases were classified via cytology/histology as normal, HPV infection, condyloma, low-grade squamous intraepithelial lesion (LSIL), high-grade squamous intraepithelial lesion (HSIL) and carcinoma. HPV infection was studied via polymerase chain reaction (PCR) using two PCR primer sets, to determine DNA integration. p53 gene changes were investigated by single-strand conformation polymorphism (SSCP) analysis.

RESULTS: One normal case, $7 \mathrm{HPV}$ infections, 6 condylomas, 7 LSIL, 14 HSIL and 8 cancers were found, with $95 \%$ positive for HPV genome when tested using both $\mathrm{L} 1$ and E6 primers. HPV 16 was most prevalent $(73.1 \%)$. HPV 16 DNA was integrated within the host genome in 3 LSIL. One LSIL progressed to HSIL by 13 months after first diagnosis. Among HPV 16-positive HSIL cases, 50\% contained integrated viral DNA. HPV 16 E2 gene disruption was seen in 7 cancers (87.5\%) Only smal-cell carwas seen in 7 can ins 16 E2 gmalcell carcinoma showed intact HPV 16 E2 gene. Abnormal $\mathrm{p} 53$ bands detected by PCR/SSCP were observed in 4 cases: 2 squamous carcinoma with parametrium (exon 8) and two cervical intraepithelial neoplasia (CIN) III (exons 5 and 7). A cases presented HPV 16 E2 gene loss.

CONCLUSIONS: The sample had a high rate of highrisk HPV detected in benign and malignant lesions: high cervical cancer burden; HPV 16 DNA integration in all except one case of cancer; $p 53$ gene changes in CIN III and in invasive cancer cases associated with DNA integration.

KEY WORDS: HPV. Viral. DNA. Integration. Gene. Cervical. Lesions. 
panicolaou exam, by three examiners per slide. For women with abnormal cervical cytology, biopsies were performed.

The cases were then classified by our Service as normal, HPV infection, low-grade squamous intraepithelial lesions (LSIL - CIN I, cervical intraepithelial neoplasia), high-grade squamous intraepithelial lesions (HSIL - CIN II and III), and carcinoma (in situ carcinoma, squamous invasive carcinoma, adenocarcinoma, small-cell carcinoma).

Samples were incubated for 4 hours at $50^{\circ}$ $\mathrm{C}$ in $200 \mathrm{ml}$ of digestion buffer (10 mM Trishydrochloric acid pH 8.3, 1 mM EDTA pH $8.0,0.5 \%$ Tween 20 , proteinase $\mathrm{K}$; final concentration of $400 \mu \mathrm{g} / \mathrm{ml}$ ). Later, they were extracted with phenol-chloroform-isoamyl alcohol (25:24:1). DNA was precipitated with one-tenth volume of $0.3 \mathrm{M}$ sodium acetate and three volumes of $100 \%$ ice-cold ethanol, washed with $70 \%$ ethanol, air-dried and suspended in $50 \mu \mathrm{l}$ of sterile water.

MY09/11 consensus primers, which amplify 450-bp (base pair) DNA sequences within the L1 region of HPV, were used to detect generic HPV DNA. Amplification was carried out in $50 \mu \mathrm{l}$ of reaction mixture (1 X polymerase chain reaction [PCR] buffer, 200 mM dNTPs, $1.5 \mathrm{mM} \mathrm{MgCl}$, 50 pmol of each primer, $0.25 \mathrm{U}$ unit of Taq polymerase, and $5 \mu \mathrm{l}$ of sample) with 35 cycles of amplification. Each cycle included a denaturation step at $94^{\circ} \mathrm{C}$ for 1 minute, an annealing step at $55^{\circ} \mathrm{C}$ for 2 minutes, and a chain elongation step at $72^{\circ} \mathrm{C}$ for 2 minutes using DNA Thermal Cycler (Perkin Elmer, CETUS). The beta-actin primers $(0.1 \mathrm{pmol}$ each), which amplify a 330-bp region of the human DNA, were used as an internal control. Polymerase chain reaction products were analyzed on $1.3 \%$ agarose gel with ethidium bromide staining for visualization of DNA under ultraviolet light and their molecular weight was determined by comparison with a 100-bp DNA ladder.

Human papillomavirus typing was done by polymerase chain reaction amplification using primers from the $\mathrm{E} 6$ gene DNA sequences of HPVs 6, 11, 16, 18, 31, 33, and 35. These primers yielded 230, 89, 134, 119, 97, 132 and 186-bp fragments, respectively. ${ }^{13}$ The PCR included steps at $94^{\circ} \mathrm{C}$ for 30 seconds, $60^{\circ} \mathrm{C}$ for 1 minute, and $72^{\circ} \mathrm{C}$ for 1 minute. Negative controls for background contamination did not

\begin{tabular}{|c|c|c|}
\hline Exon & Nucleotide sequence $\left(5^{\prime}-3^{\prime}\right)$ & PCR product size (bp) \\
\hline \multirow[t]{2}{*}{5} & TGT TCA CTT GTG CCC TGA CT & 310 \\
\hline & AGC AAT CAG TGA GGA ATC AG & \\
\hline \multirow[t]{2}{*}{6} & TGG TTG CCC AGG GTC CCC AG & 223 \\
\hline & TGG AGG GCC ACT GAC AAC CA & \\
\hline \multirow[t]{2}{*}{7} & CTT GCC ACA GGT CTC CCC AA & 248 \\
\hline & AGG GGT CAG CGG CAA GCA GA & \\
\hline \multirow[t]{2}{*}{8} & TTG GGA GTA GAT GGA GCC T & 313 \\
\hline & AGA GGC AAG GAA AGG TGA TA & \\
\hline
\end{tabular}

\begin{tabular}{|c|c|c|c|c|c|c|c|c|c|c|}
\hline \multirow[t]{2}{*}{ Cytology/histology } & \multicolumn{10}{|c|}{ HPV types } \\
\hline & 6 & 11 & 16 & 18 & 33 & 6,11 & 6,16 & 6,33 & 16,18 & 16,33 \\
\hline Normal $(\mathrm{N}=1)$ & & & & $\begin{array}{c}1 \\
* * *\end{array}$ & & & & & & \\
\hline $\operatorname{HPV}(\mathrm{N}=7)^{*}$ & & & $\begin{array}{c}5 \\
* * *\end{array}$ & & & & 1 & & & \\
\hline Condyloma $(\mathrm{N}=6)$ & & & 2 & & & 1 & 1 & 1 & 1 & \\
\hline LSIL $(N=7)$ & 2 & & $\begin{array}{c}3 \\
\star * *\end{array}$ & & $\begin{array}{c}1 \\
* \star *\end{array}$ & & & 1 & & \\
\hline HSIL $(N=14)^{* *}$ & & & $\begin{array}{c}9 \\
* * * *\end{array}$ & 1 & & & $\begin{array}{c}1 \\
* * *\end{array}$ & & 1 & \\
\hline Carcinoma ( $N=8)$ & & & 5 & & & & & & 2 & 1 \\
\hline Total $=43$ & 2 & & 24 & 2 & 1 & 1 & 3 & 2 & 4 & 1 \\
\hline
\end{tabular}

*One type not identified; ** HPV infection not detected in two cases; ** ${ }^{*}$ One HIV-positive case; *** * One HIV-positive case progressed to cancer. add to the DNA template. The polymerase chain reaction run was completed by extension for 10 minutes at $72^{\circ} \mathrm{C}$.

HPV 16 E2 type-specific primers, which amplify 1026-bp fragments, were used to determine DNA integration. The following primers were used: sense 2810-5' ATGAAAATGATAGTACAGAC-2819 and antisense 3836-5' CCAGTAGACACTGTAAATAG-3818. ${ }^{14}$ Absence of the E2 gene was considered to be a sign of $\mathrm{E} 2$ region disruption. The PCR was done as above.

The primers used for polymerase chain reaction amplification of $\mathrm{p} 53$ gene exons 5 to 8 and resulting product sizes are given in Table 1 . The PCR was carried out in a volume of $20 \mu \mathrm{l}$ consisting of $1 \mathrm{X}$ buffer, (Tris- $\mathrm{HCl}$ $\mathrm{pH}$ 8.0, $50 \mathrm{mM} \mathrm{KCl}), 50 \mu \mathrm{M}$ dNTPs, 1.5 $\mathrm{mM} \mathrm{MgCl}, 1 \mu \mathrm{M}$ of each primer, $0.25 \mathrm{U}$ unit of Taq polymerase, and $1 \mathrm{ml}$ of sample. It was hot-started by the addition of the reaction mixture at $94^{\circ} \mathrm{C}, 35$ cycles of 30 seconds at $94^{\circ} \mathrm{C}, 1$ minute at $60^{\circ} \mathrm{C}$, and 1 minute at $72^{\circ} \mathrm{C}$. The polymerase chain reaction amplification was completed by extension for 10 minutes at $72^{\circ} \mathrm{C}$. The positive controls were DNA from tumor specimens, whereas negative control for background contamination did not add to the DNA template. Extracted DNA from a benign wart was used as a normal control. Polymerase chain reaction products were visualized by electrophoresis performed at room temperature for 3 hours at $30 \mathrm{~mA}$. Single-strand DNA for single-strand conformation polymorphism (SSCP) analysis was produced by combining equal volumes of PCR product and formamide-loading buffer (95\% formamide, $10 \mathrm{mM}$ EDTA, $0.05 \%$ bromophenol blue, 0.05 xylene cyanol) and heating at $95^{\circ} \mathrm{C}$, for 10 minutes. The reaction was left on ice until submitting to electrophoresis. Non-denaturing polyacrylamide gel (49:1 acrylamide-bisacrylamide ratio) was used. After the run, the gel was fixed in 7.5\% acetic acid, washed, and silver-stained. Briefly, the gel was soaked in $10 \%$ ethanol and $1 \%$ nitric acid, and immersed in impregnation solution, visualized in developing solution, and fixed in $10 \%$ acetic acid.

RESULTS

In accordance with the cytological/histological diagnosis, we found one normal case, seven HPV infections, six condylomas, seven ILSIL, fourteen HSIL and eight carcinomas. The average age of patients with malignant lesions was about 45 years. Among the 43 women, six (14\%) were also infected with the 
human immunodeficiency virus (HIV). The results are summarized in Table 2 .

Ninety-five percent of the patients (41) were positive for the presence of HPV genome when they were tested using both L1 and E6 primers. Out of 43 samples, $67.4 \%$ (29) were positive for at least one virus type and $25.5 \%$ (11) presented infections by multiple types. Out of six cases of condyloma, four were associated with squamous intraepithelial lesion and all of them were positive to HPV. The study revealed that fourteen women had no complaint but had several kinds of cervical lesions including three HSIL and one in situ carcinoma. All except one were HPV-infected. HPV 16 was the most prevalent type (60.4\%) in single infections and both single and multiple infections $(73.1 \%)$. Thus, low-risk types were detected in $18.6 \%$, HPV 18 in $14 \%$ and HPV type 33 in $9 \%$ of the cases. HPV 16 was found in $100 \%$ of the carcinomas alone or in association with type 18 or 33 .

The HPV 16 DNA appeared also to be integrated within the host genome in three out of seven low-grade squamous intraepithelial lesions. However, one of these patients had progressed to HSIL by thirteen months after the first diagnosis. Among high-grade squamous intraepithelial lesion cases positive to HPV 16, 50\% (7/14) contained viral DNA in the integrated state. Disruption of the $16 \mathrm{E} 2$ gene was seen in all seven cancer cases (87.5\%) whereas only the small-cell carcinoma showed intact 16 E2 gene (Table 3).

Abnormal bands of p53 gene were observed in four cases: two squamous carcinoma with parametrium involvement (exon 8) and two CIN III (exons 5 and 7, respectively, Figure 1). One carcinoma had poor prognosis after 24 months. All cases presented loss of the HPV 16 E2 gene.

The persistence of HPV 16 was seen in four out of five patients treated for CIN III or in situ carcinoma following conization. To verify persistent HPV infection, the PCR test was done when the patients came back for routine follow-up three months after surgery. Only one in situ carcinoma case had the viral clearance demonstrated. One case (CIN III) infected with HPV 16 and 18 had their HPV 16 but not HPV 18 cleared. All patients had their borderline tissue freed of abnormal cells. After two years, three out of four HPV 16 infected patients did not present recurrence of the lesions. However, one HIV seropositive woman who presented CIN III progressed to invasive carcinoma 11 months after surgery.

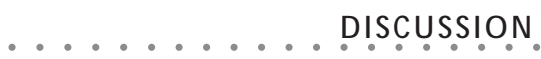

The main findings of this prospective study were: HPV DNA identified in $95 \%$ of all cases; a high rate $(86 \%)$ of high-risk HPV detected in benign as well as in malignant lesions; high burden of cervical cancer; HPV 16 DNA integration in all except one case of cancer; p53 gene changes in CIN III; and invasive cancer cases associated with DNA integration.

Infection with high-risk human papillomavirus types is frequent among sexually active women, with incidence ranging from 15 to $40 \% .^{2}$ However, the majority of the infections are found to be transient because most individuals develop a specific immune response. ${ }^{15}$ When the infection persists, precancer lesions may develop. About $1 \%$ of the general population present genital warts and $4 \%$ of all women have cervical precancerous lesions. ${ }^{16}$

In the population studied, human papillomavirus presence is associated with $85,7 \%$ high-grade squamous intraepithelial lesion and $100 \%$ carcinoma. The mean age of patients with malignant lesions was about 45 years, considered low in comparison with developed countries. In spite of the random feature in the enrollment of the patients, the women in this sample came from lower-income classes. Moreover, the Hospital Universitário Antônio Pedro is the main general hospital in a large densely populated geographical area. The lack of public healthcare clinics for providing appropriate attendance of severe dysplasia among women and also for its adequate treatment oblige this hospital to receive a high number of these cases. Therefore, these are women with little or no access to annual $\mathrm{Pa}$ panicolaou exams that would detect inflammatory or pre-neoplastic lesions (rather than neoplastic lesions) and prevent their malignant evolution. This, in association with other cofactors, may contribute to the disproportionately high rate of pre-cancerous and cancerous lesions observed in our sample. Lack of access to healthcare, poor nutrition, multiple parities, human immunodeficiency virus (HIV) and other sexually transmitted diseases (STD) also increase the susceptibility to cervical carcinogenesis in our population.

Another remarkable finding was the high rate of HIV-positive women who were infected with human papillomavirus. It is an indication of the misinformation about health monitoring among poor Brazilian people. Heterosexual transmission without using a condom is the main route to female human immunodeficiency virus infection. The presence of other sexually transmitted diseases, such as human papillomavirus infection, promotes breaks in the genital tract and increases the susceptibility to acquiring the human immunodeficiency virus. ${ }^{17}$

In an extensive molecular epidemiological study, Villa et al. ${ }^{18}$ found that infections with non-European variants of HPV 16 and 18 had a general tendency to persist more frequently and to be more associated with pre-invasive lesions. In their analysis, 33\% (15/46) women infected with European variants were non-white

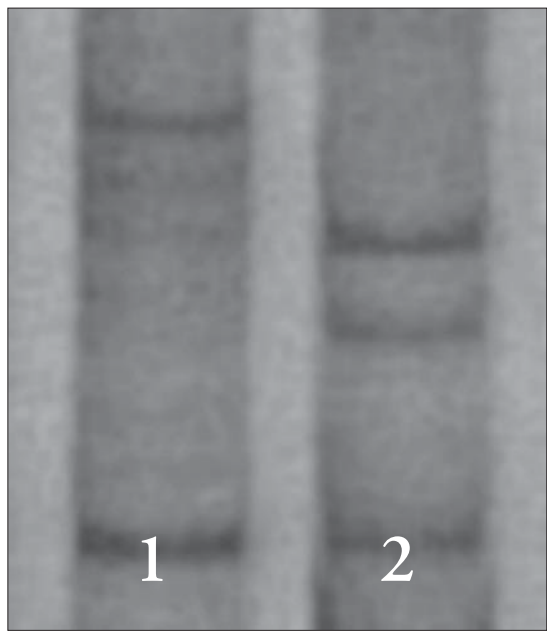

Figure 1. Screening of p53 mutation on exon 5 by polymerase chain reaction/single-strand conformation polymorphism. Number 1: normal run. Number 2: abnormal band. (CIN III).

Table 3. Human papillomavirus (HPV) detection in carcinoma cases and Type 16 E2 integration

\begin{tabular}{llccc} 
No of case & Age & Histological type & HPV types & 16 E2 integrity \\
\hline 3 & 41 & Squamous carcinoma & 16,18 & No \\
15 & 38 & In situ adenocarcinoma & 16,3 & No \\
21 & 37 & Adenocarcinoma/HPV & 16 & No \\
23 & 33 & Squamous carcinoma & 16 & No \\
28 & 43 & Squamous carcinoma/HPV & 16 & No \\
30 & 68 & Small cell carcinoma & 16 & Yes \\
33 & 57 & In situ carcinoma & 16 & No \\
38 & 40 & In situ carcinoma & 16,18 & No \\
\hline
\end{tabular}


as compared to $58 \%(11 / 19)$ infected with nonEuropean variants in the same ethnic category. It is worth noting that out of the eight cancer cases in our sample, seven (87.5\%) were nonwhite women. It may be possible that, in addition to the co-factors above mentioned, nonEuropean variants of HPV 16 harbored in nonwhite patients have contributed to increasing the rate of cervical cancer in this study.

In most cervical immortalized cells, highrisk HPV DNA often integrates into the cellular genome. The integration is processed throughout the E2 gene by disrupting some part of it and causing overexpression of the E6 and E7 proteins. This results in the loss of antioncogenic function in $\mathrm{p} 53$ and $\mathrm{Rb}$ proteins. On the basis of these events, we investigated the physical state of HPV 16 DNA using the polymerase chain reaction assay. The result was no different from other reports. ${ }^{9,19,20}$ We found loss of the E2 gene in $42.8 \%$ of low-grade squamous intraepithelial lesion and in $50 \%$ of high-grade squamous intraepithelial lesions. One low-grade squamous intraepithelial lesion case had progressed to high-grade squamous intraepithelial lesion by thirteen months after the first diagnosis. These data support the hypothesis that integration mainly happens at an early stage in the development of cervical neoplasia. It is possible that the increased expression of the E6 and E7 proteins may result in a selective growth advantage over cells harboring individualized HPV 16 DNA.

In a study on Korean women, 92.2\% of HPV 16 cancers revealed pure or mixed forms of integrated DNA. ${ }^{14}$ We found a lack of E2 gene in $87.5 \%(7 / 8)$ of the carcinomas. The intact E2 gene form was only seen in smallcell carcinoma. This has also been observed by other researchers. ${ }^{14}$

We detected $\mathrm{p} 53$ gene changes in four cases (14\% of the CIN III and $25 \%$ of the in situ carcinoma). All of them contained integrated HPV 16 DNA, thus showing that human papillomavirus infection and $\mathrm{p} 53$ gene alterations are not excluding events for cancer development. In a study to determine p53 mutation by polymerase chain reaction/single-strand conformation polymorphism and sequencing techniques, point mutation was detected in 11\% (5/46) of HPV-infected cervical carcinoma and no mutation was found in two HPV-negative cases. ${ }^{21}$ The rapid progress of squamous invasive cancer observed in our sample may suggest a synergic effect of the two events. However, the low frequency of the p53 gene changes (19\% CIN III/ in situ carcinoma) in comparison with the high frequency of high-risk human papillomavirus infection (85.7\% CIN III/in situ carcinoma) strengthens the view that $\mathrm{p} 53$ inactivation by human papillomavirus proteins plays a major role in the pathogenesis of cervical cancer.

Human papillomavirus detection following conization even when CIN III and in situ carcinoma were successfully treated is more likely to result in viral persistence than a new infection. However, the residual human papillomavirus did not promote recurrent disease over a two-year period in most of the women surgically treated. The obvious immune failure of one HIV-seropositive patient allowed the recurrence of the disease and its progression to invasive cancer.

Although cervical cancer is a preventable disease, the lack of an effective public healthcare police hinders the reduction of this malignancy among low-income women in particular.
1. Pisani P, Parkin DM, Bray F, Ferlay J. Estimates of the worlwide Pisani P, Parkin DM, Bray F, Ferlay J. Estimates of the worlwide
mortality from 25 cancers in 1990. Int J Cancer 1999;83(1):18-29.

2. Noronha V, Mello W, Villa L, et al. Papilomavírus humano associado a lesóes de cérvice uterina. Rev Soc Bras Med Trop 1999; 32(3):235-40

3. Lopes ER, Rebelo MS, Abreu E, Silva VLC, Eisenberg ALA, Lavor MF. Comportamento da população brasileira feminina em relação ao cancer cérvico- uterino. J Bras Ginecol 1995;105(11/12):505-15

4. Haddad N, Silva MB. 2001 Mortalidade por neoplasmas em mulheres em idade reprodutiva - 15 a 49 anos - no estado de São Paulo, Brasil, de 1991 a 1995. Rev Assoc Med Bras 2001;47(3):221-30.

5. Muñoz N. Human papillomavirus and cervical cancer. In: Franco E, Monsonego J, eds. New development in cervical cancer screening and prevention. Cambridge: Blackwell Science, 1997.p.3-13.

6. Schiffman MH, Bauer HM, Hoover RN, et al. Epidemiologic evidence showing that human papillomavirus infection cause most cervical intraepithelial neoplasia. J Natl Cancer Inst 1993;85(12):958-64.

7. Ho GY, Bierman R, Beardsley L, Chang CJ, Burk RD. Natural history of cervicovaginal papillomavirus infection in young women. N Engl J Med 1998;338(7):423-8.
8. Bosch FX, Manos MM, Muñoz N, et al. Prevalence of human papillomavirus in cervical cancer: a worldwide perspective. International biological study on cervical cancer (IBSCC) Study Group. J Natl Cancer Inst 1995;87(11):796-802.

9. Park TW, Fugiwara H, Wright TC. Molecular biology of cervical cancer and its precursors. Cancer 1995;76(Suppl 10):1902-13.

10. Lane DP. Cancer. p53, guardian of the genome. Nature 1992;358(6381):15-6.

11. Greenblatt MS, Bennett WP, Hollstein M, Harris CC. Mutations in the $\mathrm{p} 53$ tumour suppressor gene: clues to cancer etiology and molecular pathogenesis. Cancer Res 1994;54(18):4855-78

12. Bremer GL, Tieboschb AT, van der Putten HW, de Haan J, Arends JW. p53 tumor suppressor gene protein expression in cervical cancer: relationship to prognosis. Eur J Obstet Gynecol Reprod Biol 1995;63(1):55-9.

13. Tinos $Y$, Manos $M$. Detection and typing of genital human papillomaviruses. In: Innis M, Gelfand D, Sninsky J, White T, eds. PCR protocols: a guide to methods and application. San Diego: Academic Press 1990.p.356-67.

14. Park JS, Hwang ES, Park SN, Ahn HK, Um SJ, Kim CJ, Kim SJ, Namkoong SE. Physical status and expression of HPV genes in cervical cancers. Gynecol Oncol 1997;65(1):121-9.

15. Hildesheim A, Schiffman M, Bromley C, et al. Human papillomavirus type 16 variants and risk of cervical cancer. J Natl Cancer Inst 2001;93(4):315-8.

16. Mougin C, Dalstein V, Prétet JL, Gay C, Schaal JP, Riethmulle D. Epidémiologie des infections cervicales à papillomavirus. Recent Knowledge. Presse Med 2001;30(20):1017-23.

17. Trindade MP, Schiavo MR. Comportamento sexual das mulheres em relação ao HIVA,AIDS. DST. J Bras Doenças Sex Transm 2001;13(5):17-22.

18. Villa LL, Sichero L, Rahal P, et al. Molecular variants of human papillomavirus types 16 and 18 preferentially associated with cervical neoplasia. J Gen Virol 2000;81(Pt 12):2959-68

19. Das BC, Sharma JK, Gopalakrishna V, Luthra UK. Analysis by polymerase chain reaction of the physical state of human papillomavirus type $16 \mathrm{DNA}$ in cervical preneoplastic and neoplastic lesions. J Gen Virol 1992;73(Pt 9):2327-36.

20. Klaes R, Woerner SM, Ridder R, et al. Detection of high-risk cervical intraepithelial neoplasia and cervical cancer by amplification of transcripts derived from integrated papillomavirus oncogenes. Cancer Res 1999;59(24):6132-6.

21. Nakagawa S, Yoshikawa H, Jimbo H, et al. Elderly Japanese women with cervical carcinoma show higher proportions of both intermediate-risk human papillomavirus types and $\mathrm{p} 53$ mutations. Br J Cancer 1999;79(7-8):1139-44. 


\section{Publishing information.}

Ledy do Horto dos Santos Oliveira, PhD in Biological Sciences (Microbiology), Universidade Federal Fluminense, Niterói, Rio de Janeiro, Brazil.

Eliane de Vasconcelos Machado Rodrigues, MD. Gynecologist, School of Medicine, Universidade Federal Fluminense, Niterói, Rio de Janeiro, Brazil.

Ana Paula Terra Alvim de Salles Lopes, CAPES grantholder, MSc student in Experimental Pathology, Universidade Federal Fluminense, Niterói, Rio de Janeiro, Brazil.

André de Paula Fernandez, CNPq scientific initiation grantholder, student at the School of Medicine, Universidade Federal Fluminense, Niterói, Rio de Janeiro, Brazil.

Silvia Maria Baeta Cavalcanti, PhD in Biological Sciences (Microbiology), Universidade Federal Fluminense, Niterói, Rio de Janeiro, Brazil.

Sources of funding: CNPq (grant no. 470257/01-6) and FAPER (grant no. E-26/170.137/2001)

Conflict of interest: Not declared

Date of first submission: August 27, 2002

Last received: November 8, 2002

Accepted: December 16, 2002

Address for correspondence

Ledy do Horto dos Santos Oliveira Universidade Federal Fluminense, Instituto Biomédico Departamento de Microbiologia e Parasitologia Rua Professor Ernani Melo, 101 Niterói/RJ - Brasil - CEP 24210-130 Tel. (+55 21) 2620-0623

E-mail: mipledy@centroin.com.br
CONTEXTO: A infecção persistente por papilomavírus humano (HPV) de alto risco tem sido associada ao carcinoma cervical. Uma fase obrigatória no desenvolvimento deste câncer é a integração do DNA viral ao DNA das células hospedeiras. A integração viral promove a degradação do gene E2 do papilomavírus humano e leva a um aumento descontrolado das proteínas E6 e E7. Estas proteínas virais de HPVs oncogênicos inativam os produtos dos genes supressores de tumor p 53 e Rb. Inativação da proteína p53 é o resultado de vários fatores incluindo mutação no gene para $\mathrm{p} 53$.

OBJETIVO: Investigar lesōes cervicais associadas à infecção por papilomavírus humano, o estado físico do DNA viral e alteraçóes no gene para p53 em um grupo de mulheres atendidas em um serviço público de saúde.

TIPO DE ESTUDO: prospectivo, não-controlado.

LOCAL: Serviço de Patologia Cervical, Ambulatório de Ginecologia da Faculdade de Medicina, Universidade Federal Fluminense.

PARTICIPANTES: 43 mulheres atendidas em consulta ambulatorial de rotina para prevenção às lesōes cervicais.

VARIÁVEIS ESTUDADAS: Pela citologia/histologia os casos foram classificados como normal, infecção por papilomavírus humano, condiloma, lesão cervical de baixo graus, lesão cervical de alto grau e carcinoma. A presença de papilomavírus humano foi detectada por reação de polimerase em cadeia (PCR) utilizando-se dois pares de oligonucleotídeos. Para determinar a integração do DNA viral, usaram-se oligonucleotídeos específicos para o gene E2 do tipo HPV 16 que amplificam um fragmento de 1.026 pares de base. Alteraçōes no gene para $\mathrm{p} 53$ foram investigadas por
RESUM O

polimorfismo conformacional da fita simples.

RESULTADOS: Foi detectado um caso de cérvice normal, sete infecçōes por papilomavírus humano, seis condilomas, sete lesōes cervicais de baixo graus, 14 de alto grau e oito carcinomas. $\mathrm{O}$ estudo revelou que 14 mulheres sem queixas de doença genital eram portadoras de lesōes de vários tipos incluindo três lesōes cervicais de alto grau e um caso de carcinoma in situ. $95 \%$ das pacientes foram positivas para a presença do genoma de HPV quando testadas para os genes $\mathrm{L} 1$ e E6, com prevalência do HPV tipo 16 (73.1\%). Detectamos DNA do HPV 16 integrado ao genoma hospedeiro em três dos sete casos de lesões cervicais de baixo grau. Entretanto, um destes pacientes progrediu a lesão cervical de alto grau 13 meses após o primeiro diagnóstico. Entre os casos de lesão cervical de alto grau positivos para $\mathrm{HPV}$ $16,50 \%$ continham o DNA viral no estado integrado foi encontrado. A falta do gene E2 do HPV 16 foi observada em sete dos carcinomas $(87.5 \%)$ e somente no carcinoma de células pequenas foi detectado o gene E2. Bandas anormais do gene $\mathrm{p} 53$ detectadas por PCR/ SSCP foram observadas em quatro casos: dois carcinomas escamosos com envolvimento do paramétrio (exon 8) e dois casos de NIC III (exons $5 \mathrm{e} 7$, respectivamente). Todos os casos apresentaram perda do gene E2 do HPV 16.

CONCLUSŌES: A amostra analisada tinha alta taxa de HPV de alto risco detectada tanto em lesões benignas como em lesões malignas; alto índice de câncer cervical; integração do DNA do HPV 16 em quase todos os casos de câncer com uma exceção; alteraçôes no gene para p 53 em NIC III e em câncer invasivo associadas à integração do DNA.

PALAVRAS-CHAVE: HPV. Integração. DNA Viral. Gene. Lesões Cervicais. 